JOURNAL OF SECURITY AND SUSTAINABILITY ISSUES ISSN 2029-7017 print/ISSN 2029-7025 online

2020 March Volume 9 Number 3

https://doi.org/10.9770/jssi.2020.9.3(34)

Scopus

\title{
ISSUES OF PUBLIC SECURITY: LEGAL CONSEQUENCES OF DETERMINING UNFORESEEABLE EXTRAORDINARY EVENTS
}

\author{
Jānis Načiščionis ${ }^{1}$, Vladas Tumalavičius ${ }^{2}$, Una Skrastiņa ${ }^{3}$, Juris Radzevičs ${ }^{4}$, Dalia Prakapiené5 \\ ${ }^{1,3}$ Turība University, Graudu Str. 68, LV-1058 Riga, Latvia \\ ${ }^{2,5}$ The General Jonas Žemaitis Military Academy of Lithuania, Šilo Str. 5A, Vilnius LT-10332, Lithuania \\ ${ }^{2}$ Institute of Humanities and Social Sciences of Daugavpils University, Parades Str. 1, Daugavpils, LV-5401, Latvia \\ ${ }^{4}$ Riga City Council, Ratslaukums Str. 1, LV-1050
}

E-mails: ${ }^{1}$ janis.naciscionis@turiba.lv; ${ }^{2} v l a d a s . t u m a l a v i c i u s @ g m a i l . c o m ; 3$ una.skrastina@gmail.com; jiuris.radzevics@inbox.lv; ${ }^{5}$ dalia.prakapiene@lka.lt

Received 10 May 2019; accepted 30 November 2019; published 30 March 2020

\begin{abstract}
The basis of every state is in its democratic system and ability to defend it. Therefore, a government has legal rights to immediately declare emergency situation, responding to crisis, catastrophes or unforeseen extraordinary events. The topicality of the research is determined by the emergency situation declared by the Cabinet of Ministers in 2019 in the administrative territory of Riga City in regard to waste management, in order to provide the Riga municipality with an opportunity to conclude negotiated procedure without prior publication. Even though state's democratic system demands to act immediately in any case of such action, it must be legal since the public, whose life, health and property might be endangered, relies on it, as well as budget is spent on it. However, the mutual application of regulatory enactments in practise cause issues because it is not always clear how to identify and separate such situations and which regulatory enactment is applicable in each specific case. The aim of the research is to determine what is included in the definition of unforeseeable extraordinary events in the context of public procurement, when the government has rights to declare an emergency situation, what are the legal consequences of declaring emergency situation and provide suggestions for dealing with the issue highlighted by the research. In order to reach the set goal, the following tasks were defined: carry-out analysis of regulatory enactments, research the judicature of the European Union and Latvia, conclusions of legal scholars and evaluate the practice of legal act application. The research utilizes descriptive, comparative, dogmatic, historical, systemic, teleological method and analytical interpretation of regulatory enactments.
\end{abstract}

Keywords: public procurement; unforeseeable extraordinary events; emergency situation.

Reference to this paper should be made as follows: Načiščionis, J., Tumalavičius, V., Skrastina, U., Radzevičs, J., Prakapienė, D. (2020). Issues of Public Security: Legal Consequences of Determining Unforeseeable Extraordinary Events, Journal of Security and Sustainability Issues 9(3): 1117-1127. https://doi.org/10.9770/jssi.2020.9.3(34)

JEL Classifications: K 100, H570, H830.

Additional disciplines: law; economics.

\section{Introduction}

The guarantor of the sustainable development of the state is a stably safe society and its economy. Over the past few years, public safety issues in various problemic areas have already been addressed by many scientists (e.g. Tumalavičius et al. 2016; Tumalavicius, 2017; Kuril, 2018; Bernardi, 2019; Reinhold et al., 2019; Vigliarolo, 2020; Chehabeddine, Tvaronavičienè, 2020). 
Decision-making issues by state institutions in emergency situations have not been studied and require a deeper analysis and study.

Situations that are not foreseeable but require immediate action often arise in public administration. That means that, for state administration continuity purposes, clear and unambiguous lawful basis that would allow making a lawfully based decision as soon as possible is necessary. In regulatory enactments and practice these situations are referred as extraordinary events, emergency situations or crises, and often they are emphasized as unforeseeable. From a decision-maker it requires not only the ability to correctly identify each such case, but also immediate legal action and consequence liquidation.

The topicality of the research is determined by the Cabinet of Ministers (hereafter - CM) order No: 432 on September 12, 2019 which declared an emergency situation for 3 months in the administrative territory of Riga City and Riga municipality was ordered to conclude the negotiated procedure in accordance specified by the Public Procurement Law (hereafter - PPL), coordinating tenderer requirements (technical specifications) and the results of the negotiated procedure with the Ministry of the Environmental Protection and Regional Development (hereafter - MEPRD).

\section{Public Procurement Law}

Public Procurement is a process which results in a signed procurement contract. In accordance with PPL, it is a public construction work, supply, or service contract for pecuniary interest concluded in writing between one or several contracting authorities and one or several economic operators (PPL, 2016: 1). Public procurement has six procurement procedures, including negotiated procedure, which is a procurement procedure where the contracting authority without prior publication of the contract notice, consults with the economic operators selected by it and organises negotiation with one or several of them regarding the conditions of the procurement contract (PPL, 2016: 1). One of such cases when the contracting authority can apply negotiated procedure is due to unforeseeable extraordinary events (PPL, 2016: 8).

PPL Article 8, Paragraph seven, Point three determines that the contracting authority has rights to apply negotiated procedure if as a result of extraordinary events unforeseeable by the contracting authority, a situation has objectively occurred, where, for reasons of urgency, it is not possible to apply an open procedure, a restricted procedure or a competitive procedure with negotiation. The above-mentioned circumstances which justify extraordinary situation may not depend upon the activities of the contracting authority. According to PPL Article 60, Paragraph nine, Point three states that a procurement contract may be concluded immediately without complying with Paragraph six of this Article, meaning without the waiting period, during which a tendered whose rights have been violated might submit a complaint regarding infringements of the procurement procedure to the Procurement Monitoring Bureau (hereafter-PMB), if the negotiated procedure is being applied.

Recital 50 of the Directive 2014/24/EU of the European Parliament and of the Council of 26 February 2014 on public procurement and repealing Directive 2004/18/EC (hereafter -Directive) emphasizes that in view of the detrimental effects on competition, negotiated procedures without prior publication of a contract notice should be used only in very exceptional circumstances. Article 18 of that Directive underlines that the procurement shall not be made with the intention of excluding it from the scope of that Directive or of artificially narrowing competition. That directive provides a possibility for the Member States to determine that contracting authorities may award public contracts by a negotiated procedure without prior publication in so far as is strictly necessary where, for reasons of extreme urgency brought about by events unforeseeable by the contracting authority, the time limits for the open or restricted procedures or competitive procedures with negotiation cannot be complied with. The circumstances invoked to justify extreme urgency shall not in any event be attributable to the contracting authority (Directive, 2014:32). According to Recital 109 of that Directive, the notion of unforeseeable circumstances refers to circumstances that could not have been predicted despite reasonably diligent preparation of the initial award by the contracting authority. 
Court of Justice of the European Union (hereafter - CJEU) has recognized the contracting entity's rights to use negotiated procedure without prior publication of contract notice if for the reasons of extreme urgency brought about by events unforeseeable by the contracting entities, the time limits laid down for open and restricted procedures cannot be adhered to. The case-law has made it subject to three cumulative conditions, namely an unforeseeable event, extreme urgency rendering impossible the observance of the time limits laid down for calls for tenders, and a causal link between the unforeseeable event and the extreme urgency resulting therefrom (CJEU Nr. C-394/02, 2005: 40). As derogations from the rules relating to procedures for the award of public procurement contracts, the provisions must be interpreted strictly. Also, the burden of proof lies on the party seeking to rely on them (CJEU Nr. C-394/02, 2005: 33). Identical conclusions have been expresses in the CJEU judgement in case No. C-126/03 paragraph 23 and in 20/06/2013 judgement in case No. C-352/12 paragraph 52 .

Urgency alone in the view of Republic of Latvia (hereafter - LR) Supreme Court (hereafter - SC) does not justify carrying out negotiated procedure without prior publication of contract notice because it is additionally necessary to establish that the situation has been caused by extraordinary events unforeseeable by the contracting authority that do not depend on it. SC points out that unforeseeable events may be events that cannot be objectively foreseen with due diligence. Consecutively, extraordinary events are such events which do not correspond to the normal order (SC No. SKA-426/2018, 2018: 14).

The authors point out that legal scholars (Telles, Butler 2014: 3.2.1) emphasize certain freedom of action and subjectivity by contracting authority's when assessing the criteria for the existence of extraordinary events. In addition, evaluating CJEU case law, it is noted that urgency can be determined on the basis of objective evidence, and that an event that creates urgency cannot be foreseeable and cannot be attributed to the contracting authority's own conduct (Arrowsmith, 2014: 1075). Scholars also point to the role of the CJEU in the evolution of European Union (EU) public procurement legislation (Bovis, 2012: 2).

When explaining the notion of unforeseeable extraordinary events, the PMB refers to circumstances which go beyond the normal economic and social situation (such as an accident or natural disaster) and there is an immediate necessity to procure to deal with the consequences of the unforeseeable extraordinary events. The negotiated procedure applies to purchase of goods, services or construction works to an extent that is strictly necessary to prevent an emergency.

The authors conclude that the long-standing operation of the EU legal norms in public procurement area, CJEU and LR case law, as well as PMB explanations have creates legally understandable and applicable notion of extraordinary urgency. Urgency, in the authors' opinion, is characterized by a time constraint on the conduct of procurement procedures which logically means that the contracting authority needs the services or goods immediately. Furthermore, Article 32 of the Directive emphasizes the circumstance of extreme urgency, highlighting a state of exception- extreme urgency not urgency that leads different legal consequences. Therefore, the authors agree with the opinion of other researchers that is important to differentiate urgency from extreme urgency and justify it accordingly (Telles, Butler 2014: 3.2.1). The authors stress that the aforementioned circumstances have to require immediate actions. Although, undeniably, in evaluating the circumstances the contracting authority has freedom of action, both case law and studies have accentuated the existence of causal link, which means a link between cause and consequences, namely, harmful consequences that could occur without an adequate reaction from state administration to an extraordinary circumstances or event. The SC does not recognize circumstances that were dependent on the contracting authority as urgent, for example, not timely preparation of procurement or neglect of possible appeal in procurement. The authors underline that urgency in itself is not the basis for negotiated procedure since in applying negotiated procedure intended by PPL Article 8, Paragraph seven, Point three, there need to be a circumstance or event that objectively was not foreseeable, that is, goes beyond the normal and social situation (e.g. natural disaster). It is possible to agree with the opinion expressed by other researchers (Surmovičs, 2013) that this exceptional procedure can only be utilised to prevent the consequences of extraordinary and unforeseeable events and the urgency and unpredictability of these cannot be supposed, in particular, the contracting authority cannot be held liable for their occurrence, thus 
excluding the possibility of unduly applying the negotiated procedure. In the authors' view, it means that it is essential to objectively state, firstly, unforeseeable event or situation, which has not occurred as a result of an action or omission of an action by the contracting authority, secondly, extreme urgency, namely, immediate action to prevent a threat to public interest, thirdly, causal link between unforeseeable event and extreme urgency. Without even one of these circumstances, there is no legal basis to apply negotiated procedure without prior publication.

At the same time, the authors emphasize that when purchasing a service or a good to prevent unforeseeable extraordinary situation, the contracting authority's actions are not unlimited because the procurement is limited in volume, namely, only to prevent an emergency situation and cannot go beyond the volume that is necessary to deal with an emergency situation. That follows from Article 32 of the Directive where it is stated that procedure can be applied only to the extent that is strictly necessary. It is understandable that in case of such situation in it impossible to predict or forecast the volume. Nevertheless, the authors believe that technical specifications of goods, services or construction works and contract deadlines might indicate that the procurement is for other purposes, for example, for one year which has no relation to extreme urgency circumstances, for instance, daily road maintenance.

Even though PPL and CM Regulation No. 107 "Tendering Procedures for Procurement Procedures and Design Contests" describes the contracting authority's actions in case of negotiated tendering procedure (CM No.107, 2017: 2.6.), the authors, studying the issue purchasing goods or services or mobilizing material resources in response to disasters or similar situations to prevent hazards, that it is not only possible under the PPL but also under other legal frameworks.

\section{Legal aspects of resource involvement in the event of a disaster}

According to Civil Protection and Disaster Management Law (hereafter - CPL) Article 1, disaster is an accident which has caused human casualties or endangers human life or health, caused damage or threat to people, the environment or property, and also inflicted or inflicts significant material and financial losses and exceeds the daily capacity of the responsible State and local government authorities to prevent the devastating conditions. Article 4 of this law defines man-made disasters or anthropogenic disasters as technogenic disasters caused by a release of chemical, radioactive and biological substances, fires in buildings and structures, explosions, ruptures in dams and other hydrotechnic structures, damages to energy networks, accidents in utility networks, collapse of buildings and structures or vehicle accidents. Local disasters are such disasters where the scale of damage caused by a disaster does not exceed the borders of the administrative territory of one local government. Disaster response measures consists of a set of the measures which are performed in order to reduce or eliminate devastating conditions and the consequences caused thereby, to prevent or reduce harm to people, the environment and property, while measures for the elimination of consequences are a set of measures which are performed in order to ensure at least the minimum basic needs of inhabitants related to the survival of people and to stop or reduce threat to human health, the environment and property. Response measures and measures for the elimination of consequences include also rescue operation, as well as CPL provides the possibility to involve legal and natural persons, and also resources at their disposal in response and elimination of consequences measures (CPL, 2016).

In order to stop and prevent extension of fire and dangerous factors related thereto which endanger natural persons, material valuables and the environment, or to liquidate obstacles, which hinder fire-fighting and the performance of rescue operations, the manager of fire-fighting and rescue operations is entitled to with the consent of owners (authors' underlining) use movable or immovable property of natural and legal persons in the performance of operations (Fire Safety and Fire-fighting Law, 2001: 15, 20).

CM Regulation 07/03/2017 No. 131 "Regulations Regarding the Involvement of the Resources of Legal or Natural Persons in Response and Elimination of Consequences Measures or Fire-fighting or Rescue Operations and Procedures for the Calculation of Compensation for the Incurred Expenditures and Losses" determine that 
the operations manager and the resource owner (possessor) shall enter into a written agreement (authors' underlining) on the involvement of resources at the place of the incident; however, if not possible, within a period of five working days after the involvement of the resources in the relevant measure. The consequences of this agreement is that the resource owner (possessor) has the right to be compensated in full amount for the actual expenditures and losses incurred as a result of involving resources in the operations, but the lost profits shall not be compensated (CM Regulation No.131, 2017: 6).

The authors view that disaster definition and actions are determined by two crucial criteria:

1) consequences of the event or their probability - human casualties, endangerment of human life or health, caused damage or threat to the environment or property;

2) the event surpasses the responsible state's or local government's institutions ability to deal with the hazardous circumstances. Undeniably, natural or man-made disasters can endanger not only the environment, property, but also, most importantly, public health and life. Due to these circumstances, state rescue services have to act immediately with adequate resources to respond accordingly, perform rescue operations, eliminate consequence, specifically, remove hazard to human life and health, the environment, as well as protect their properties. Taking into account the definition of a disaster, it is possible to conclude that it goes beyond the regular capacity of various state services to respond to the scale and intensity of resources required, thus the state services need to use the property available to private persons in such situations.

In authors' opinion, it is highly important to stress the time aspect, that is, the time period from the event that surpasses the regular capacity of various state services to eliminate hazards or ability to predict and forecast resources, till the response measures. As opposed to the time aspect, namely, urgency, it is essential to note that the previously discusses regulatory enactments of disaster management demand that resources be involved on the basis of a written agreement, which is the basis for a compensation.

Parliamentary investigation commission's gave a final report on state's actions, evaluating the causes of a tragedy that occurred in Zolitude on November 21, 2013, and further measures taken to improve regulatory enactments and the work of state and local government administration in order to prevent re-occurrence of such tragedy in the future, as well as measures for elimination of consequences. The final report stated that on November 21, 2013 in Riga, Zolitude a building collapsed, leading to 54 human casualties, and concluded that rescue operations involved no only the human resources available to the state and local government, but also involved material and technical equipment at the disposal of private contractors. Thus it is clear what special equipment urgently needs to be purchased for rescuers to improve their work in the event of a possible tragedy (Saeima, 2015).

On April 29, 2014 CM issued order No.186 in order to compensate expenditures that occurred from involving private person resources in rescue operations. Total expenditure reached 101713 euro. The annotation of this order notes, that basing on the CM regulation, an agreement was closed, private contractors' requests was reviewed and decision prepared in order to compensate the expenditures and losses due to their resources involved in response measures (The Ministry of the Interior, 2014).

The authors conclude that the previously mentioned example shows a contradiction between a necessity for an urgent action in an emergency situation and the fact that involving required resources to eliminate endangerment depends on the resource owner's (possessor's) consent and written agreement upon that. At the same time, the authors believe that in situations with in identical circumstances - unforeseeable, not attributable to the contracting authority's actions, which objectively demands urgent action, form into two legally different ones, namely, according to PPL Article 8, Paragraph 3, Point seven organized negotiated procedure and according to CPL Article 6, Paragraph four intended involvement of resources in the basis of a written agreement. In both cases, therefore, the good, service or construction works are provided for compensation in the form of written agreement. It means that, on the one hand, there is a freedom of action, and, on the other hand, there is a legal uncertainty since there are no clear criteria that would allow separating these cases. 


\section{Declaring emergency situation}

National security concept approved by the Parlament emphasizes that state's constitutional apparatus is part from the notion of internal security which is closely associated with the base values determined by the Constitution of the Republic of Latvia: national independence, democracy and territorial integrity (CM 2019, 7). National security concept notes that it is necessary to strengthen and develop civil protection system, civilmilitary cooperation, ensuring interinstitutional action and resource utilization in a case of a national threat (Saeima, 2015, 4.1).

Emergency situation is a special legal regime, during which the $\mathrm{CM}$ has the right to restrict the rights and freedoms of State administrative and local government institutions, natural persons and legal persons, as well as to impose additional duties to them. Emergency situation shall be declared by the CM for a definite time period, but no more than three months. Emergency situation may be declared in case of such threat to national security, which is related to a disaster, danger thereof or threat to the critical infrastructure, if safety of the State, society, environment, economic activity or health and life of human beings is significantly endangered (Saeima, 2013: 4,5).

Law "On Emergency Situation and State of Exception" (hereafter - ESL) Article 8, Paragraph one, Points three and four state that in declaring emergency situation, the CM has the right to stipulate procedures for economic activity or restrictions to such activity; access to goods, medicinal products, energy resources, services and other material and technical resources (Saeima, 2013:8). It has to be noted that applying the norms of this law does not limit other laws as far as they are not in contradiction with order stated by tis law and legally determined special procedures to prevent emergency situation or state of exception (Ministru kabinets, 2012). Emergency situation is a special legal regime that is mainly attributable to civil (non-military) crises. One of the authors of this law security policy expert Kaspars Druvaskalns explains that in practice it could be mostly refer to natural disasters (for instance, storms, whirlwinds, earthquakes, torrential rains, floods, hail, heavy frost, snow storms, icing, snowfall and ice congestion, heat, drought, forest and peat bog fires), man-made disasters (such as industrial accidents with chemical, radioactive and biologically active material leaks, building fires, explosions, vehicle accidents, dam breaks, utilities and energy service breaks, building collapses, public disorder and terror), as well as dangerous mass people, animal and plant diseases (Laganovskis, 2013).

For instant, CM issued order No.4 On declaration of the emergency situation (Ministru kabinets, 2011). This order determined in accordance with PPL Article 3 Paragrph three point 2 not to apply the relevant public procurement legislation, if their application could create harm to protecting national interest, and essential protection of national interests is decided by the CM (CM 2011: 7). Similarly, somewhat controversial situation appeared in Riga City related to waste management after Competition Council (hereafter - CC) had suspended the implementation of the waste collection concession contract for a period of 20 years (CC 2019).

The CM decided to declare an emergency situation in the administrative territory of Riga City starting from 11/09/2019 until the moment when the decision of the Competition Council No. 19 "On interim measures" is no longer in force, but not longer than 11/12/2019 with the aim to secure the continuity of waste collection and disposal in the administrative territory of Riga City without increasing administrative or financial burden waste generators or governors during an emergency situation. To ensure the afore mentioned, Riga Council was ordered to immediately apply and till 13/09/2019 conclude negotiated procedure according to PPL, coordinating tenderer requirements (technical specifications) and the results of the negotiated procedure with the MEPRD (Ministru kabinets, 2019: 3.3., 3.5.). The order was justified with Article 4 Paragrahp 2 Point two and Paragraph 2 Point one of CPL, Article 4, 5, 6, 8 of ESL, to prevent threat of anthropogenic disaster that is associated with potential environmental and public health hazards.

According to the annotation of this order, emergency situation was necessary to prevent threat of anthropogenic disaster that is associated with potential environmental and public health hazards if starting from 15/09/2019 waste collection and disposal would be suspended or seriously hindered in the administrative territory of Riga 
City, the basis of which serves the decision on 09/09/2019 No.19 with which Riga City municipality and SIA "Getlini" have the obligation to immediately stop 14/06/2019 the execution of concession contract "On implementation of Riga City waste management system" starting from agreement date in part which refers to nonrecycled and separated waste collection and transportation (MEPRD, 2019: 2).

The Supreme Court points out that the Competition Council is the only competent institution in the system of state administration system, agreed by the market supervision, ensuring free market principles are abided by. The circumstance that one of the market participants operational aspects has been transferred to other state administration institution competence, does not limit Competition Council's competence because each state administration institution exercise competence in its own field (SC 2016: 8). The Court stresses that the main manifestation of the principle state administration's unity id that all state administration institutions are organized in united hierarchical system and it must be adhered to that each institutions duty is to work within its area of competence (SC 2016: 14).

Evaluation declaring emergency situation in Riga, the authors conclude that it has been declared on the basis of probability of an event, namely, not collecting and disposing waste, which could be due to legally taken decision of a state administration institution, because at the moment of the order the only factual circumstances was local government's concession contract and Competition Council's decision to suspend it. Analysing legal consequences, the authors highlight that the only aim to declare emergency situation was to secure the process of negotiated procedure without prior publication of contract notice. In authors' view, it means that the consequences of declaration of emergency situation are to restrict free competition and economic activity because negotiated procedure allows immediate signing of an agreement with a specific contractor.

In the authors' opinion, it is important to evaluate if the decision complies with the Constitution of the Republic of Latvia. Section 105 of the Constitution determines that everyone has the right to own property and property rights may be restricted only in accordance with law. The authors point out that Constitutional Court has recognized that a person's economic interest that is related to commercial activity is included in the first sentence of the Constitution's Section 105 (Constitutional court 2014: 10.1). From the mentioned it can be said that it is necessary to determine whether restriction of such free economic activity and competition has been properly followed.

As noted by legal scholar K. Balodis, such regulatory enactment has to be issued, basing on law, published or otherwise available and clearly formulated in order for the addressee could understand her rights and duties, as well it has to comply with the rule of law. In turn, law has to clearly state competent institution's authority and how to exercise it, taking into account legitimate aim of the instrument to provide protection to an individual from arbitrary interference (Balodis, 2011: 471).

This view is based on the Constitutional Court's recognition that in order to assess whether a restriction of a fundamental right has been established by law, it needs to be verified that the law is clearly enough formulated so that a person could understand the substance of the rights and duties arising therefrom and could predict the consequences of application (Constitutional court Nr.2015-01-01: 14).

The authors draw attention to the fact that the commission of Constitutional rights has already expressed opinion that inclusion of separate section in the Constitution on human right restriction in a case of war, state of exception and emergency situation should be seriously considered (Levits et al, 2011: 191). In addition, it is emphasized that Section 90 of the Constitution affirms predictability, clarity and understandability of legal norms, thus clearly ambiguous and in complex words stated norm cannot be attributed to a private person in a manner which would impose obligations, restrictions on rights or sanctions of a punitive nature.

The Treaty on the Functioning of the European Union Article 3, Part one, point b states that it has competence in establishing of the competition rules necessary for the functioning of the internal market (LESD, 2012:3). Thus, in the authors' view, ensuring competition is an important part of international commitments that Lat- 
via has taken upon by joining the EU, simultaneously transferring the creation of necessary regulation in the Union's competence. In turn, it is closely related with public procurement whose regulation is included in the Directive and taken over in PPL with one of the aims being free competition of tenderers (PPL Section 2). The $\mathrm{CM}$ by declaring emergency situation and ordering different procurement procedures than stated in the PPL, give basis to a conclusion that international commitments are being ignored are in contradiction with the goals of the PPL. Additionally, the authors believe that there is foundation to claim that, by restricting competition, normal commercial activity is disrupted which might be considered as violation of the Constitution's Section 105, which can occur in the order defined in the Constitution's Section 116 and on a basis of a clearly formulated law.

Assessing the included government's rights to determine special order of economic activity or its restriction in Emergency situation law Article 8, Paragraph one, Point three, the authors believe that they are formulated unclearly and too generally to give basis to restrict competition that would manifesting in establishing a different order that stated by the relevant law, that is, PPL.

\section{Conclusions and recommendations}

Decisions taken by the state administration institutions within their competence are not recognized as unforeseeable extraordinary events in public procurement.

PPL Article 8, Paragraph tree, Point seven given justification is a permanent legal notion and does not include in itself declaring emergency situation on the basis of Emergency situation law. In order to apply negotiated procedure, it is necessary to state legal justification specified by PPL and declaring emergency situation does not in itself include rights to determine different procurement procedures.

In the event of a disaster, extreme urgency is the reason to procure goods and services both guided by PPL norms and Emergency situation law because in both cases there i san identical legal justification and consequences, as well as agreement is needed.

In order to perform response measures in the event of a disaster, respective regulatory enactments intend written agreement with the resource owner (possessor) and it creates a significant risk not to acquire the resources in the necessary time and volume.

Additional in-depth research is need about the possibility of resource inclusion for disaster management without owner's agreement.

Additional research is needed to specify the notion of "special procedures for economic activity" law "On Emergency Situation and State of Exception" Section 8, Paragraph one, Point three, establishing clearly criteria and government's authority understandable to everyone.

\section{References}

Arrowsmith, S. 2014. The law of public and utilities procurement: regulation in the EU and UK. Vol. 1. Sweet \& Maxwell.

Balodis, K. 2011. Latvijas Republikas Satversmes komentāri (Comments on the Constitution of the Republic of Latvia). VIII nodaḷa. Cilvēka pamattiesības.. Rīga, Latvijas Vēstnesis, 459-479.

Bernardi, A. 2019. The capability approach and organizational climate as tools to study occupational health and safety, Insights into Regional Development, 1(2), 155-169. https://doi.org/10.9770/ird.2019.1.2(6)

Bovis, C. H. 2012. Public procurement in the EU: Jurisprudence and conceptual directions. Common market law review, 49(1), 247289. Retrieved: http://www.ejtn.eu/PageFiles/17838/BOVIS\%20CMLRev.pdf 
Civilās aizsardzības un katastrofas pārvaldīšanas likums. Latvijas Republikas likums. (Civil Protection and Disaster Management Law) Adoption: 05.05.2016. Entry into force: 01.10.2016. Riga, Latvijas Vēstnesis, 100, 25.05.2016.

CJEU Judgment of 18 November 2004 Commission of the European Communities v. Federal Republic of Germany. Case C-126/03 18.11.2004. Retrieved: http://curia.europa.eu/juris/document/document.jsf?text=\&docid=49307\&pageIndex=0\&doclang=LV\&mode=1 st\&dir $=\&$ occ $=$ first\&part $=1 \&$ cid $=3452299$

CJEU Judgment of 20 June 2013. Case C - 352/12. Retrieved: http://curia.europa.eu/juris/celex.jsf?celex=62012CO0352\&lang1=lv\& lang $2=$ EN\&type $=$ TXT\&ancre $=$

CJEU Judgment of the Court (First Chamber) of 2 June 2005. Commission of the European Communities v Hellenic Republic. Case C-394/02. Retrieved: http://curia.europa.eu/juris/document/document.jsf;jsessionid=593E900EAAADA960FC8B4CF323E5BB1E?tex $\mathrm{t}=\&$ docid $=162829$ \&pageIndex $=0$ \&doclang $=$ LV\&mode $=1$ st\&dir $=\&$ occ $=$ first \&part $=1 \&$ cid $=3451976$

Directive 2014/24/EU of the European Parliament and of the Council of 26 February 2014 on public procurement and repealing Directive 2004/18/EC Published: Official Journal, L 94,28.03.2014., pp. 65-242.

Iepirkumu uzraudzības birojs. 2018. Skaidrojums par iepirkumu veikšanu ārkārtas apstākḷu novēršanai. Retrieved: https://www.iub.gov. lv/sites/default/files/upload/skaidrojums_arkartas_apstakli_20180625.pdf

Kuril, J. 2018. Public administration for safe and secure environment: case of Slovak Republic. Entrepreneurship and Sustainability Issues, 5(3), 493-501. https://doi.org/10.9770/jesi.2018.5.3(6)

Laganovskis, G. 2013. Ārkārtējā situācija. Ko tā nozīmē (Emergency situation. What it means). Retrieved: https://lvportals.lv/ skaidrojumi/255074-arkarteja-situacija-ko-ta-nozime-2013

Latvijas Republikas Satversme. Adopted 15.02.1922. Entry in force 07.11.1922.

Levits, E., Kusiņš, G., Liepa, L., Mits, M., Rezevska, D., Ziemele, I. 2011. Konstitucionālo tiesību komisijas Viedoklis par Valsts prezidenta funkcijām Latvijas parlamentārās demokrātijas sistēmas ietvaros (Opinion of the Constitutional Rights Commission on the functions of the President in the framework of the Latvian Parliamentary Democracy System). Retrieved: http://blogi.lu.lv/tzpi/ files/2016/12/KTK_VP_FUNKCIJAS.pdf

Par ārkārtējo situāciju un izṇēmuma stāvokli (On Emergency Situation and State of Exception). Adopted 07.03.2013. Entry into force 10.04.2013. Riga, Latvijas Vēstnesis, 61, 27.03.2013.

Publisko iepirkumu likums. (Public Procurement Law) Adoption: 15.12.2016. Entry into force: 01.03.2017. Riga, Latvijas Vēstnesis, 254, 29.12.2016.

Reinhold, K., Järvis, M., Prause, G. 2019. Occupational health and safety aspects of green shipping in the Baltic Sea. Entrepreneurship and Sustainability Issues, 7(1), 10-24. http://doi.org/10.9770/jesi.2019.7.1(1)

Saeima. 2015. Nacionālās drošības koncepcija (National security concept) Adopted 26.11.2015. Entry into force 26.11.2015. Riga, Latvijas Vēstnesis, 233, 27.11.2015.

Saeima. 2019. Nacionālas drošības koncepcija (National security concept). Adopted 26.09.2019. Entry into force 26.09.2019. Rīga, Latvijas Vēstnesis, 197, 27.09.2019.

Saeima. Parlamentārās izmeklēšanas komisijas par Latvijas valsts rīcību, izvērtējot 2013.gada 21.novembrī Zolitūdē notikušās tragèēijas cēloṇus, un turpmākajām darbībām, kas veiktas normatīvo aktu un valsts pārvaldes un pašvaldību darbības sakārtošanā, lai nepieḷautu līdzīgu traǵēdiju atkārtošanos, kā arī par darbībām minētās traǵēdijas seku novēršanā galaziņojums (Parliamentary Inquiry Commissions on the Action of the Latvian State in Assessing the Causes of the Tragedy on 21 November 2013 in Zolitude, and the Follow-up to Legislation and Public Administration and Local Government Activities to Prevent Repetition of Similar Tragedies, and on Actions to Prevent Consequences final message) Adopted 27.10.2015. Rīga, Latvijas Vēstnesis, 220, 10.11.2015.

Surmovičs, A. 2013. Ārkārtas apstākḷi sarunu procedūru piemērošanā (Exceptional circumstances in the application of the negotiated procedure). Retrieved: https://zurnalsiepirkumi.lv/arkartas-apstakli-sarunu-proceduru-piemerosana/

Telles, P., Butler, L. 2014. Public Procurement Award Procedures in Directive 2014/24/EU. Retrieved: https://papers.ssrn.com/sol3/ papers.cfm?abstract_id $=2443438$

The Cabinet of Ministers. 2011. Order No.4 "Par ārkārtējās situācijas izsludināšanu" (Order No.4 on Emergency Proclamation). Adopted 06.01.2011. Entry into force 06.01.2011. Rīga, Latvijas Vēstnesis, 5, 11.01.2011.

The Cabinet of Ministers. 2014. Order No.186 Par “finanšu līdzekḷu piešķiršanu no valsts budžeta programmas "Līdzekḷi neparedzētiem 
gadījumiem“ (Order No.186 on "the allocation of funds from the State Budget Program” Contingency Funds"). Adopted: 29.04.2014. Entry into force: 29.04.2014. Rīga, Latvijas Vēstnesis, 85, 06.05.2014.

The Cabinet of Ministers. 2014. Order No.186. Adopted 29.04.2014. Entry into force 29.04.2014. Rīga, Latvijas Vēstnesis, 85, 06.05.2014

The Cabinet of Ministers. 2017. Regulation No. 107 “Iepirkuma procedūru un metu konkursu norises kārtība” (Regulation No. 107 Procurement procedures and design contests). Adopted 28.02.2017. Entry into force 02.03.2017. Rīga, Latvijas Vēstnesis, 45, 01.03.2017.

The Cabinet of Ministers. 2017. Regulation No. 131 "Noteikumi par juridiskās vai fiziskās personas resursu iesaistīšanu reaǵēšanas un seku likvidēšanas pasākumos vai ugunsgrēka dzēšanā, vai glābšanas darbos, kā arī tai radušos izdevumu un zaudējumu kompensācijas aprēkināšanas kārtību"("Rules governing the involvement of a legal or natural person in the response and relief or fire or rescue operations and the procedures for calculating the compensation for the expenses and losses incurred by a legal or natural person). Adopted 07.03.2017. Entry into force: 10.03.2017. Rīga, Latvijas Vēstnesis, 51, 09.03.2017.

The Cabinet of Ministers. 2019. Order No. 432 "Par ārkārtējās situācijas izsludināšanu Rīgas pilsētas administratīvajā teritorijā" (Announcement of the emergency situation in the administrative territory of Riga city). Adopted 12.09.2019. Retrieved: https://www. vestnesis.lv/op/2019/187.16

The Competition Council. 2019. Decision No.19 of 19 September 2019. Retrieved: https://www.kp.gov.lv/files/documents/20190909_ KP_Interim\%20measures.pdf

The Constitutional court. 2014. Judgment case No. 2013-21-03. Adopted: 12.12.2014. Rīga, Latvijas Vēstnesis, 250, 16.12.2014.

The Constitutional court. 2015. Judgment case No.2015-01-01. Adopted: 02.07.2015. Rīga, Latvijas Vēstnesis, 129, 06.07.2015.

The Ministry of the Environmental Protection and Regional Development. 2019. Ministru kabineta rīkojuma projekta "Par ārkārtējās situācijas izsludināšanu Rīgas pilsētas administratīvajā teritorijā” sākotnējās ietekmes novērtējuma ziṇojums (anotācija). Retrieved: http://tap.mk.gov.lv/lv/mk/tap/?pid=40477411\&mode=mk\&date=2019-09-11

The Ministry of the Interior. 2014. The annotation of order No.186 by 24.09 .2014 . Retrieved: http://tap.mk.gov.lv/lv/mk/tap/?pid=403 20380\&mode $=$ mk\&date $=2014-04-22$

The Supreme Court of Latvia. 2016. Case No.A43017613, SKA - 416/2016

The Treaty on the Functioning of the European Union. 2012. Retrieved: https://eur-lex.europa.eu/legal-content/LV/TXT/?uri=celex\% $3 \mathrm{~A} 12012 \mathrm{E} \% 2 \mathrm{FTXT}$

Tumalavičius, V.; Ivančiks, J.; Karpishchenko, O. 2016. Issues of society security: public safety under globalisation conditions in Lithuania. Journal of Security and Sustainability Issues. 5(4): 545-570. DOI: http://dx.doi.org/10.9770/jssi.2016.5.4(9)

Tumalavicius, V. 2017. Viešojo saugumo užtikrinimo teisiniai aspektai Lietuvoje: dabarties tendencijos ir procesai. Mokslo studija [Legal Aspects of Public Security Ensuring in Lithuania. Research Study]. Vilnius: The General Jonas Žemaitis Military Academy of Lithuania. -219 p.; Available on the Internet: http://www.lka.lt/lt/moksline-veikla/leidiniai/leidiniu-sisteminis-katalogas/socialiniaimokslai/teise.html

Ugunsdrošības un ugunsdzēsības likums (Fire Safety and Fire-fighting Law). Adopted 24.10.2002. Entry into force 01.01.2003. Publicēts: Latvijas Vēstnesis, 165, 13.11.2002.

Vigliarolo, F. 2020. Economic phenomenology: fundamentals, principles and definition. Insights into Regional Development, 2(1), 418429. http://doi.org/10.9770/IRD.2020.2.1(2) 


\section{About contributors:}

Jānis NAČISČIONIS - Dr. iur, Professor. Research interests: public administration ORCID ID: 0000-0002-6313-8010

Vladas TUMALAVIČIUS - Dr. iur.; Research interests: Legal regulation of public safety and administration; Issues of national, state and regional security and sustainability.

ORCID ID: 0000-0002-0811-0074

Una SKRASTIN,A - Dr. iur., is a researcher of The Turiba University. Research interests: public administration, public procurement ORCID ID: 0000-0001-8727-2698

Juris RADZĒEIČS - PhD candidat, executive director of Riga city council. Research interests: public admnistration, public procurement, the local goverment.

ORCID ID: 0000-0003-3526-8683

Dalia PRAKAPIENE் - Dr., assoc. prof. Research interests: organizational management, public management, research methodology. ORCID ID: 0000-0002-4415-2327

This work is licensed under the Creative Commons Attribution International License (CC BY) http://creativecommons.org/licenses/by/4.0/ 